\title{
Relationship Between Ginsenoside Rg3 and Metabolic Syndrome
}

\author{
Hyunji Lee ${ }^{1,2}$, Gyeyeong Kong ${ }^{1,2}$, Quangdon $\operatorname{Tran}^{1,2}$, Chaeyeong Kim ${ }^{1,2}$, Jisoo Park ${ }^{1,2,3^{*}}$ \\ and Jongsun Park ${ }^{1,2 *}$
}

${ }^{1}$ Department of Pharmacology, College of Medicine, Chungnam National University, Daejeon, South Korea, ${ }^{2}$ Department of Medical Science, Metabolic Syndrome and Cell Signaling Laboratory, Institute for Cancer Research, College of Medicine, Chungnam National University, Daejeon, South Korea, ${ }^{3}$ Department of Life Science, Hyehwa Liberal Arts College, Daejeon University, Daejeon, South Korea

OPEN ACCESS

Edited by: Ruiwen Zhang, University of Houston,

United States

Reviewed by:

Dayun Sui,

Jilin University, China

Liang Liu,

The General Hospital of Northern

Theater Command, China

Sung-Jin Yoon,

Korea Research Institute of Bioscience and Biotechnology (KRIBB),

South Korea

*Correspondence: Jisoo Park basel97@dju.kr Jongsun Park insulin@cnu.ac.kr

Specialty section:

This article was submitted to Ethnopharmacology,

a section of the journal

Frontiers in Pharmacology

Received: 10 December 2019

Accepted: 30 January 2020

Published: 25 February 2020

Citation:

Lee H, Kong G, Tran Q, Kim C, Park J and Park J (2020) Relationship Between Ginsenoside Rg3 and Metabolic Syndrome.

Front. Pharmacol. 11:130. doi: 10.3389/fphar.2020.00130
Metabolic syndrome is an important public health issue and is associated with a more affluent lifestyle. Many studies of metabolic syndrome have been reported, but its pathogenesis remains unclear and there is no effective treatment. The ability of natural compounds to ameliorate metabolic syndrome is currently under investigation. Unlike synthetic chemicals, such natural products have proven utility in various fields. Recently, ginsenoside extracted from ginseng and ginseng root are representative examples. For example, ginseng is used in dietary supplements and cosmetics. In addition, various studies have reported the effects of ginsenoside on metabolic syndromes such as obesity, diabetes, and hypertension. In this review, we describe the potential of ginsenoside Rg3, a component of ginseng, in the treatment of metabolic syndrome.

Keywords: ginsenoside, metabolic syndrome, Rg3, obesity, NAFLD

\section{INTRODUCTION}

Ginseng, a traditional herb, is widely used in southeast Asian countries and is gaining popularity worldwide due to its medicinal properties (Takino et al., 1982; Odani et al., 1983). The first record of therapeutic use of ginseng was in Asia about 2,000 years ago (Kim et al., 2015). The roots of ginseng plants are generally used in herbal medicines, but the leaves and fruits are also used (Li W. et al., 2019). Ginseng is produced mainly in Korea, China, and the United States (Karikura et al., 1990; Karikura et al., 1991a; Karikura et al., 1991b), and is distributed as fresh ginseng, dried ginseng, red ginseng, and related products. Ginseng is consumed as a food and health supplement, and is used medically (Lee et al., 2009; Park et al., 2012; Zhao et al., 2016; Lee et al., 2019) due to the presence of ginsenoside saponins, which are pharmacologically active (Matsuda et al., 1986; Peng et al., 2012; Tam et al., 2018; Li G. et al., 2019). As the efficacy of ginseng has been revealed, the corresponding review has been reported (Nakhjavani et al., 2019). About 150 ginsenoside saponins are known, > 90\% of which are classified as Rb1, Rb2, Rc, Rd, Re, Rg1, and Rg3. Of these, Rg3, Rg1, Rd, and Rh2 have been studied most intensively (Xie et al., 2015; Xu et al., 2016; Gao et al., 2017; Sun et al., 2017; Zhou et al., 2019). In addition to the segmentation of ginsenoside, saponin components, one ginsenoside may be classified according to its molecular form. Recently, Rg3 has been studied for the different efficacy of two forms. (Kwok et al., 2012; Fan et al., 2017; Nakhjavani et al., 2019)\}. Among many ginsenoside saponins, Rg3 is well known in the public, but not much research has been done, 
such as Rb1, Rg1, and Rb2. In addition, Rg3 is a very low ratio of less than $0.1 \%$ among ginsenosides of ginseng. Despite this low ratio, Rg3 has a pharmacological effect such as anticancer, antiinflammation, and anti-aging that is not much different from that of a high ratio such as Rb1 and Rg1.

\section{METABOLIC SYNDROME}

Metabolic syndrome is defined as a cluster of metabolic risk factors, such as abdominal obesity, an elevated triglyceride (TG) level, a reduced high-density lipoprotein cholesterol (HDL-C) level, hypertension, and impaired glucose tolerance (van Namen et al., 2019). Approximately $25 \%$ of adults worldwide suffer from metabolic syndrome (Nolan et al., 2017; Saklayen, 2018). Metabolic syndrome doubles the risk of atherosclerotic cardiovascular disease and increases that of type 2 diabetes (T2D) fivefold (Grundy, 2016). Abdominal obesity is a major risk factor for metabolic syndrome. As well as being a causal factor in many diseases and disorders, obesity also reduces the quality of life (Finkelstein et al., 2012; Ogden et al., 2014). If the recent trend continues, it is estimated that $57.8 \%$ of the world's adult population will be overweight or obese by 2030 (Finkelstein et al., 2012). In addition to obesity, non-alcoholic fatty liver disease (NAFLD) and T2D are also public health issues. NAFLD is currently the most common liver disease in Korea, as well as in the United States and Europe, where its prevalence is $20-30 \%$ (Younossi et al., 2018).

Additionally, metabolic syndrome such as obesity, insulin resistance and type 2 diabetes are closely related to chronic inflammation characterized by abnormal cytokine production and activation of the inflammatory signaling pathway network. The first clear link of this association began with the overexpression of tumor necrosis factor-alpha (TNF- $\alpha$ ) in the adipose tissue of obese mice (Hotamisligil et al., 1993). In obese mice models, a lack of TNF- $\alpha$ resulted in an improvement in insulin sensitivity and glucose homeostasis, confirming that the inflammatory response plays a critical role in the regulation of insulin action in metabolic syndrome (Uysal et al., 1997; Ventre et al., 1997).

Interest in ginsenoside, a component of ginseng, has increased recently. Among the ginsenosides, Rg3 has been reported to have antiobesity, antidiabetic, antioxidant, antiaging, anti-inflammatory, and anticancer activity (Takino et al., 1982; Hwang et al., 2009; Kong et al., 2009; Wei et al., 2012; Shin et al., 2013; Sun et al., 2017; Lee et al., 2019). In this review, we focus on the effect of $\mathrm{Rg} 3$ on components of metabolic syndrome, including obesity, T2D, hypertension, and NAFLD, as well its therapeutic potential.

\section{GINSENOSIDE RG3}

Ginsenosides are classified according to their aglycon structures: 20(S)-protopanaxadiol (ginsenosides Rb1, Rb2, Rb3, Rc, Rd, and Rg3) and 20(S)-protopanaxatriol (ginsenosides Re, Rg1, Rg2, and Rh1) (Helms, 2004). According to structural differences at the C20 position, there are two enantiomers: the 20(R) and 20(S)isomers (Kim et al., 2013). For Rg3, there are two structures, 20 (R)-Rg3 and 20(S)-Rg3, which are classified according to the C20 position (Figure 1). The clinical potential of ginsenosides in various fields of medicine has been investigated.

Ginsenoside $\operatorname{Rg} 3$ is one of several biologically active steroid saponin groups found in ginseng and has been shown to exert pharmacological effects. In addition, Rg3, as a natural compound, has antioxidant (Wei et al., 2012), antiaging (Lee et al., 2019), antiinflammatory (Yoon et al., 2015), and anticancer (Kim et al., 2014; Junmin et al., 2015). Moreover, Rg3 has shown neuroprotective activity in various models (Tian et al., 2005; Shin et al., 2013; Junmin et al., 2015). Rg3 also promotes bone formation and differentiation of preosteoblastic MC3T3-E1 cells (Siddiqi et al., 2015), and inhibits the osteoclastic differentiation of RAW264.7 cells. Rg3 inhibits differentiation by suppressing the RANKL-mediated transcription factors that regulate osteoblastic differentiation (Siddiqi et al., 2015). Also, Rg3 enhances insulin signaling, due primarily to enhanced

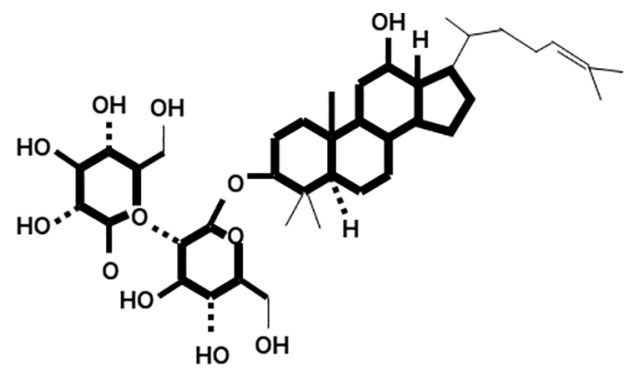

20(S)-ginsenoside Rg3

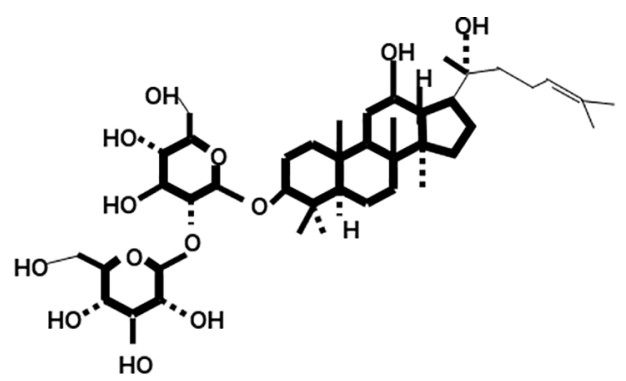

20(R)-ginsenoside Rg3

FIGURE 1 | Chemical structures of 20(S)-ginsenoside Rg3 and 20(R)-ginsenoside Rg3. 
IRS-1 expression in L6 myotubes (Hwang et al., 2009). Rg3 exerts anti-aging and antioxidant effects in the skin by restoring the function of ultraviolet (UV)-damaged mitochondria, recovering mitochondrial membrane potential and the production of ATP (Lee et al., 2019). Rg3 reportedly inhibits skin photo-aging and lightinduced increases in interleukin (IL)-6 and MMP-1 levels, in UVand infrared (IR)-exposed human dermal fibroblasts and 3D models of normal human skin. Moreover, Rg3 inhibited skin photo-aging and aided the recovery of photo-induced skin damage. (Nagar et al., 2016)

Rg3 is being studied for its effects on various diseases and symptoms. In the following section, we discuss the effects of Rg3 on metabolic syndrome and its therapeutic prospects.

\section{EFFECT OF GINSENOSIDE RG3 IN METABOLIC SYNDROME}

Metabolic syndrome refers to metabolic abnormalities associated with visceral adiposity, including hypertension, insulin resistance, dyslipidemia (involving low-density lipoprotein cholesterol [LDLC], HDL-C, and hypertriglyceridemia), and central obesity (Tariq et al., 2016). Metabolic syndrome is diagnosed when three of five metabolic abnormalities occur simultaneously. Patients diagnosed with metabolic syndrome show damage to tissues in the cardiovascular system, pancreas, and liver (Grundy, 2008; Oladejo, 2011).

\section{NAFLD}

NAFLD is characterized by histological changes similar to alcoholic hepatitis, a disease that is not associated with alcohol abuse in which TGs accumulate in the liver parenchyma (Alba and Lindor, 2003; Angulo, 2003; Wang and Liu, 2003). NAFLD was first discovered in 1980 and ranges from simple steatosis or nonalcoholic fatty liver to nonalcoholic fatty hepatitis (Ludwig et al., 1980). Due to advances in technology, NAFLD can be now diagnosed at an early stage. Nevertheless, NAFLD remains one of the most common liver diseases worldwide (Younossi et al., 1998; Zhou et al., 2012; Lonardo et al., 2013). In addition, as rates of obesity and T2D continue to increase, so too does the incidence of NAFLD. NAFLD is characterized by an increase in intrahepatic triglyceride (IHTG) content (i.e., steatosis), with or without inflammation and fibrosis (i.e., steatohepatitis) (Patel et al., 2016).

The causes of NAFLD are complex and unclear. TGs accumulate in hepatocytes when hepatic lipid influx exceeds lipid export and utilization (Browning and Horton, 2004). This lipid accumulation promotes damage to the liver and leads to hyperinsulinemia and hyperglycemia (Azzout-Marniche et al., 2000; Guillet-Deniau et al., 2002). In addition to indirectly inhibiting free fatty acid (FFA) oxidation when lipid accumulation accelerates the production of new lipid droplets, these FFAs directly damage liver cells and activate inflammatory pathways (Charlton et al., 2002; Klein et al., 2006). Under normal conditions, insulin is secreted in response to circulating glucose and converts FFA into TGs for storage (Feldstein et al., 2003). This normal metabolic process, which is impaired in NAFLD patients, results in high levels of circulating FFAs. In addition, the resulting fatty liver is only vulnerable to hepatotoxicity, which can lead to hepatocellular damage, inflammation, and fibrosis, as well as lipid peroxidation, induction of cytokine production, and mitochondrial dysfunction (Gaemers and Groen, 2006; Duvnjak et al., 2007; Petta et al., 2009; Dowman et al., 2010; Das and Balakrishnan, 2011; Colica and Abenavoli, 2018).

Rg3 has been studied as a putative treatment for fatty liver diseases, such as NAFLD. In dyslipidemic and $\mathrm{db} / \mathrm{db}$ mice, with Rg3 and probiotics improves NAFLD symptoms, reducing liver inflammation by decreasing the expression of cytokines such as IL-1 $\beta$ and phospho-p38 (p-p38) (Kim et al., 2019). In another study, high fat diet-induced mice were compared with a group treated with $\operatorname{Rg} 3$ for 8 weeks. The mice treated with $\operatorname{Rg} 3$ had lower body weight and better insulin sensitivity compared with the untreated mice. In addition, insulin signaling was higher in the liver and epididymal white adipose tissue. Therefore, Rg3 enhances insulin activity in obesity and T2D models. Furthermore, Rg3 modulates obesity through peroxisome proliferator-activated receptor gamma (PPAR $\gamma$ ) regulation, by suppressing signal transducer and activator of transcription 5 (STAT5) phosphorylation (Lee et al., 2017). Rg3 reportedly modulates alanine aminotransferase (ALT) and aspartate aminotransferase (AST) levels, which are used as markers of liver damage. This study analyzed the effects of $\mathrm{Rg} 3$ on high fat diet (HFD)-induced ALT and AST levels. Rg3 reduced the incidence of serum postoperative liver failure (PLF), and the hepatic TNF- $\alpha$ level, in high-fat diet-fed mice, and decreased the levels of hepatic lipids including TG and LDL (Nan et al., 2018). In obese insulin-resistant rats, Rg3 increased the PPAR $\gamma$ protein level and adenosine monophosphate-activated protein kinase (AMPK) phosphorylation in the liver (Ginsberg and Maccallum, 2009a). Moreover, Rg3 exerts a positive effect on fatty liver disease (Figure 2).

\section{Obesity}

Obesity, which is the major casual factor in metabolic syndrome, is a multifactorial chronic disease caused by genotype-environment interactions (Kissebah and Krakower, 1994). Obesity is a risk factor for insulin resistance and T2D (Lovejoy et al., 1996), as well as a major risk factor for cardiovascular disease (CVD); however, not all obese patients are insulin-resistant or at high risk of diabetes and CVD (Despres et al., 1990). However, excessive visceral fat accumulation increases markers of insulin resistance and the risk of diabetes (Chen and Huang, 2009; Konishi et al., 2010; Ryo et al., 2014; Smith, 2015). Obesity is accompanied by insulin resistance, i.e., impaired glucose tolerance, in which glucose uptake by the muscles is reduced. However, Rg3 increased the expression of the GLUT4 glucose transporter (Kang et al., 2008), and insulin receptor substrate 1 (IRS-1), in obese mice, thereby increasing glucose uptake by the muscles. These mechanisms explain how ginsenoside Rg3-stimulated glucose uptake occurs via the PI3K-dependent pathway, of 


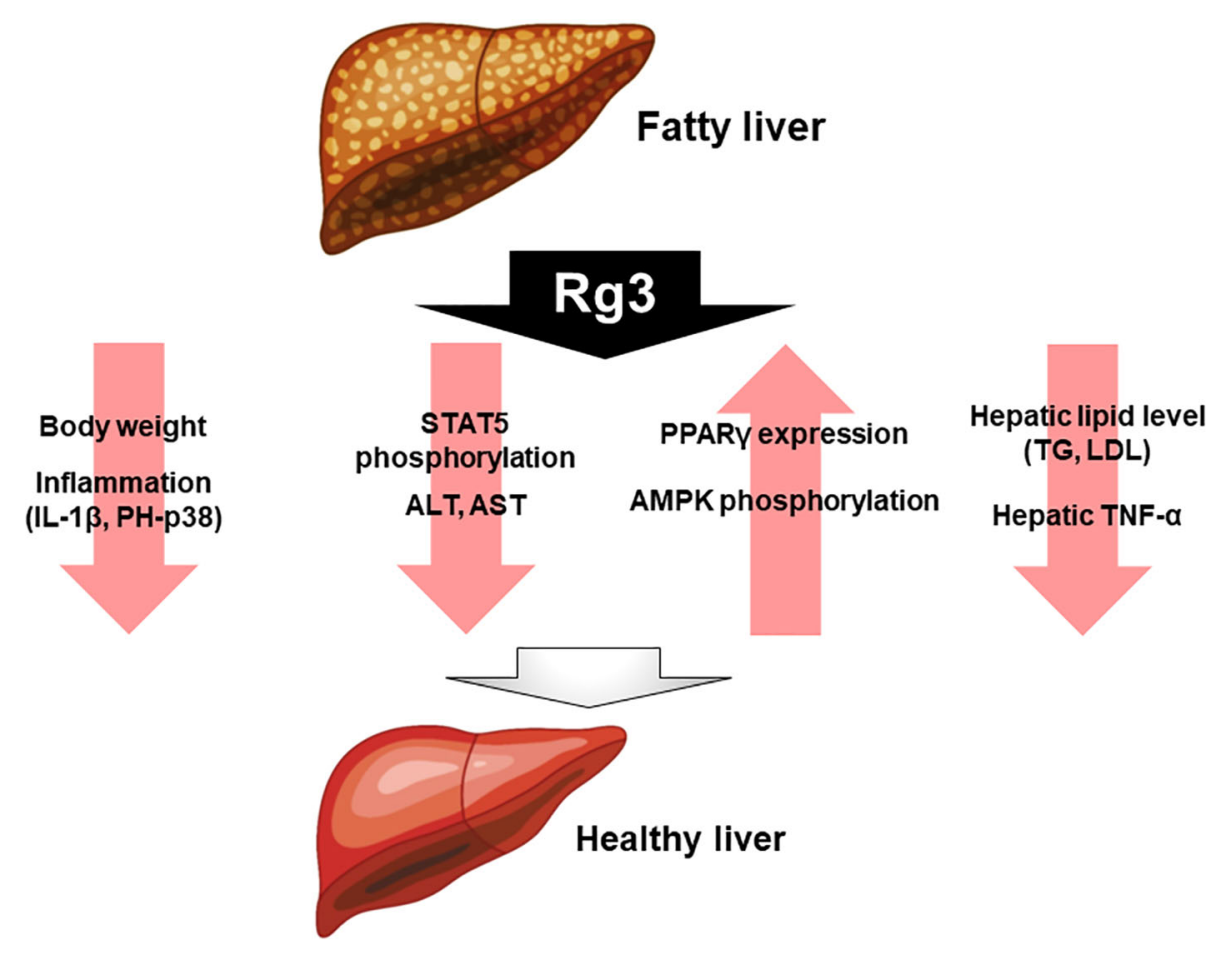

FIGURE 2 | Effect of Rg3 on fatty liver disease. Administration of Rg3 to fatty liver reduces weight loss, inflammation, and reduces liver injury markers alanine aminotransferase and aspartate aminotransferase. In addition, hepatic lipid levels and tumor necrosis factor-alpha expression levels are significantly reduced. On the other hand, PPAR $\gamma$ and AMPK phosphorylation increases, which ultimately improves healthy liver.

which IRS-1 is a component (Lee et al., 2011). Also, Rg3 exerts glucose- and weight-lowering effects by increasing the GLUT4 protein level in skeletal muscle, and the PPAR $\gamma$ protein level and AMPK phosphorylation in the skeletal muscle of obese insulin-resistant rats (Ginsberg and Maccallum, 2009a).

Excessive nutrients are deposited in undesirable locations, such as visceral fat. Nutrients converted to triacylglycerol are used as an energy source, and excess energy is deposited in areas such as the liver, heart, and skeletal muscle (Campaigne, 1990; Bjorntorp, 1991). When these fat tissues are increased due to obesity, the immune system is markedly affected (Ramsay and Caperna, 2009; Maury and Brichard, 2010; Ramanjaneya et al., 2010) and chronic diseases such as heart disease (Leong and Wilding, 1999), diabetes (Cho et al., 2002), and cancer (BasenEngquist and Chang, 2011) develop. Increased adipose tissue mass due to obesity occurs via adipocyte hyperplasia (increased number of adipocytes) and hypertrophy (increased size of adipocytes) (Lee et al., 2013). However, high-fat diet-fed mice treated with $\operatorname{Rg} 3(20-40 \mu \mathrm{M})$ not only showed reduced adipose tissue mass, but also inhibition of the production thereof (Hwang et al., 2009; Meng et al., 2018). In addition, treatment of 3T3L1 cells with Rg3 inhibits adipocyte differentiation (Hwang et al., 2009). The fat storage process is closely linked to fat production and breakdown. In particular, the genes involved in fat production, PPAR $\gamma$ and CCAAT enhancer binding protein alpha $(\mathrm{C} / \mathrm{EBP} \alpha)$, increase the levels of proteins involved in lipogenesis, including FABP4, ACC, FAS, and perilipin. Rg3 also affects adipogenesis and lipogenesis, activates the AMPK pathway (Hwang et al., 2009; Kong et al., 2009), and inhibits the expression of proteins involved in lipogenesis and adipogenesis (Kim et al., 2014). The above effects of $\operatorname{Rg} 3$ have been demonstrated in vitro, and in obese mouse models (Hwang et al., 2009; Wei et al., 2012; Lee et al., 2017) (Figure 3).

\section{Diabetes}

Patients with metabolic syndrome typically die from cardiovascular disease, T2D, or cirrhosis. Ironically, in some parts of the world where malnutrition is common, the incidence of metabolic syndrome has been increasing for decades (Ginsberg and Maccallum, 2009a; Ginsberg and Maccallum, 2009b). T2D is a growing health problem worldwide, and is closely related to the obesity epidemic (Defronzo, 2009; DeFronzo et al., 2015). T2D usually occurs as a result of an imbalance between insulin resistance and secretion (DeFronzo et al., 2015). Individuals with T2DM are at high risk of both macrovascular complications (such as cardiovascular comorbidities) and microvascular complications (including retinopathy, nephropathy, and neuropathy), owing to hyperglycemia and the presence of individual components of insulin resistance (metabolic) syndrome Environmental factors (e.g., obesity, unhealthy diet, and physical inactivity) and genetic factors contribute to several pathophysiological disorders that impair glucose homeostasis in T2D (American Diabetes, 2014; 

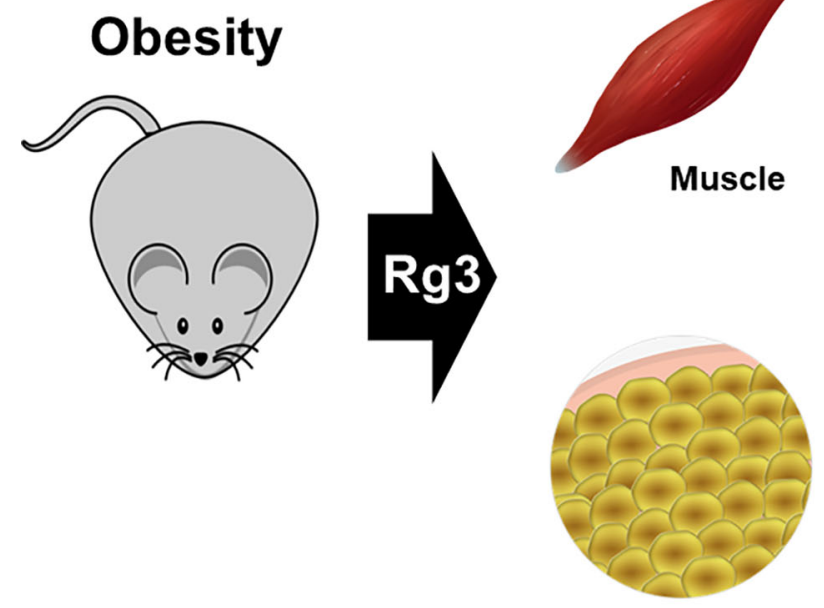

Adipose tissue

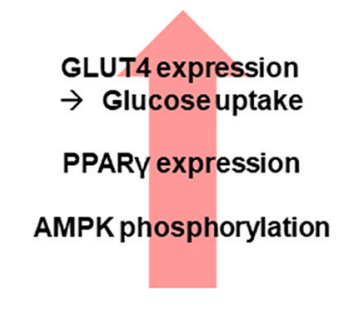

Muscle

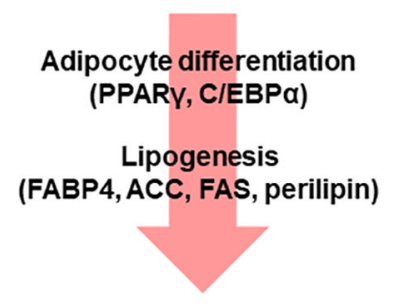

FIGURE 3 | Effect of Rg3 on obesity. Treatment of Rg3 with adipocyte in obese mouse model decreases adipogenesis and lipogenesis. This effect is shown by the reduced expression of PPAR $\gamma, \mathrm{C} / \mathrm{EBP} \alpha, \mathrm{FABP} 4, \mathrm{ACC}, \mathrm{FAS}$, and perilipin, which are proteins related to lipogenesis. In addition, the glucose uptake is increased by Rg3 and $\beta$-oxidation in skeletal muscle of the obese mouse model.

Zitkus, 2014). Increased insulin resistance due to obesity, inflammation, aging, oxidative stress, and decreased physical activity elevate insulin secretion, to overcome insulin resistance and maintain normoglycemia (Kim et al., 2018).

In the diabetes-induced Otsuka Long-Evans Tokushima Fatty (OLETF) rat model, $\mathrm{Rg} 3$ not only reduced water intake, but also body weight, by inhibiting oxidative stress and advanced glycation end-product (AGE) formation. Therefore, Rg3 improves renal function, which is impaired by T2DM. Similarly, Rg3 exerted a protective effect against type 1 diabetes (streptozotocin-induced diabetic renal damage model) by inhibiting oxidative stress and AGE formation (Yokozawa et al., 2007; Kang et al., 2008). In addition, administration of Rg3 to diabetic OLETF rats has been demonstrated to reduce body weight, as well as fasting and postprandial glucose concentrations (Ginsberg and Maccallum, 2009b). This effect is associated with increased PPAR $\gamma$ expression and AMPK phosphorylation. Rg3 improves insulin secretion, which is important in the treatment of diabetes. Insulin secretion was increased by 20(S)-Rg3 in hamster pancreatic HIT-T15 $\beta$-cells in a concentration-dependent manner. Moreover, 20(S)-Rg3 improved glucose tolerance and enhanced insulin secretion in mice with type 1 diabetes (Kang et al., 2008). Moreover, when Rg3-containing malonyl-ginsenosides were administered to streptozotocin-induced diabetic mice at $30 \mathrm{mg} / \mathrm{kg}$, the blood glucose, hepatic glycogen, and cholesterol levels decreased (Liu et al., 2009). Also, Rg3 exerts an anti-hyperglycemic effect in db/ $\mathrm{db}$ mice by stimulating glucagon-like peptide-1 secretion through the sweet taste receptor-mediated signal transduction pathway (Kim et al., 2015) (Figure 4).

\section{Hypertension}

Blood pressure is the force that circulates the blood, putting blood on the walls of the arteries of the body, the main blood vessels of the body (Howard et al., 2003). Hypertension is when blood pressure is too high. It is a serious medical condition that greatly increases the risk of heart, brain, kidney, and other disease. The cause of hypertension are diabetes and obesity due to kidney problems and nerve damage. However, sometimes the cause is unknown (Balcazar-Munoz et al., 2003; Eckel et al., 2006). In particular, hypertension caused by obesity is mostly cause by arteriosclerosis. Obesity causes lipids in the blood to accumulate in blood vessels and harden, resulting in narrowing of bold vessels and development of atherosclerosis (Defronzo, 2006; Ferrannini and Iozzo, 2006).

In spontaneously hypertensive rats, $\operatorname{Rg} 3$ not only significantly reduced renin activity but also decreased blood pressure. However, angiotensin-I converting enzyme inhibition and NO are significantly increased with compared to control (Lee et al., 2016). On the other hand, studies have reported that $\mathrm{Rg} 3$ also affects blood pressure in healthy adults. They who consumed Rg3 have decreased central and peripheral arterial pressures (Jovanovski et al., 2014). Another study compared blood pressure and blood vessel wall thickness after Rg3 administration in male mice. Mice treated with Rg3 significantly reduced blood pressure and vascular wall thickness (Nagar et al., 2016). These results suggest that Rg3 can be used as one of the therapeutic agents. Although many studies have been reported on the relationship between metabolic syndrome symptoms and Rg3, there have not been many studies on hypertension and $\operatorname{Rg} 3$ among many metabolic syndrome symptoms. Thus, further research is needed on the effects and relationship of $\operatorname{Rg} 3$ on hypertension (Figure 5). 


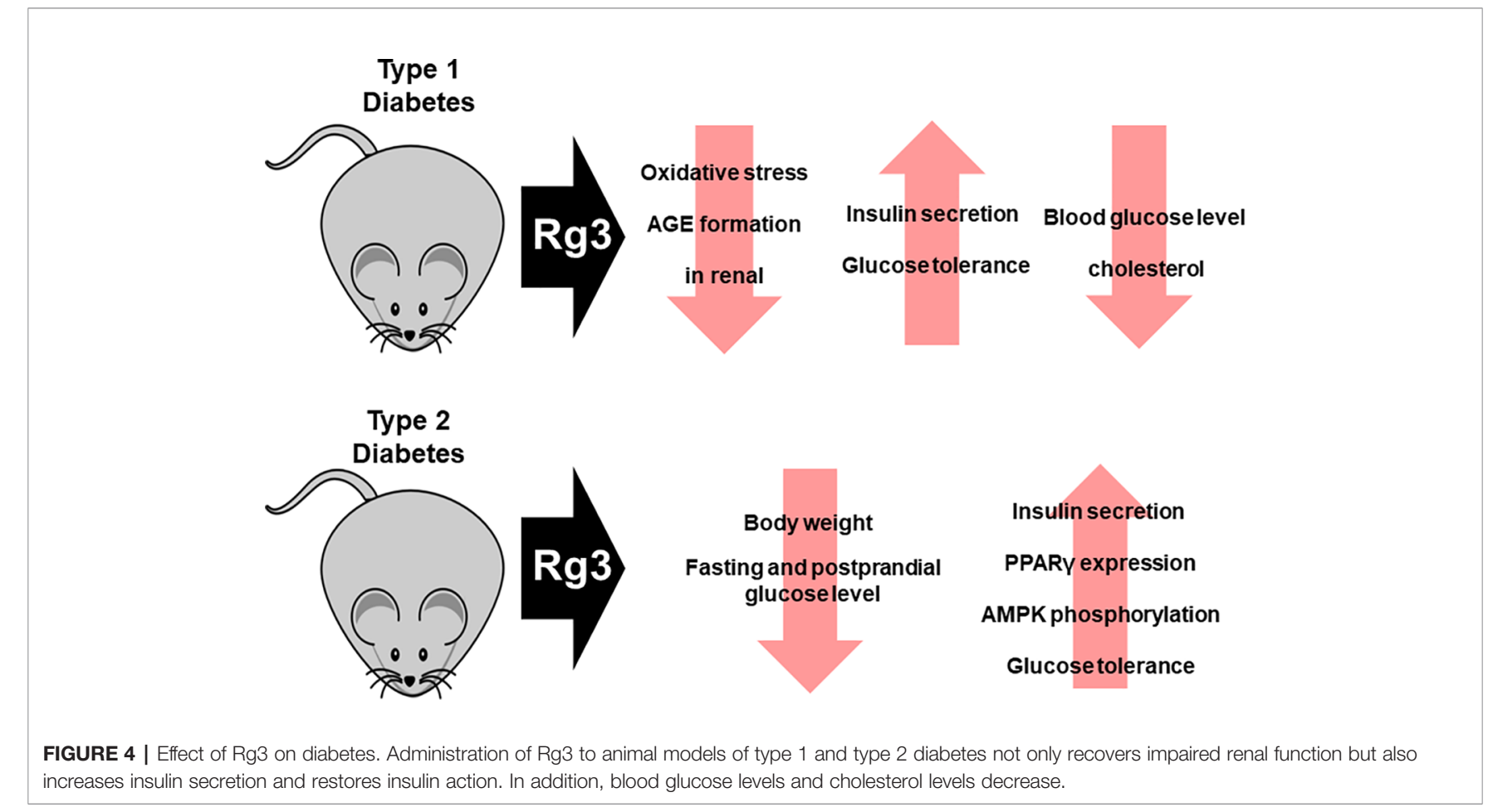

not only recovers impaired renal function but also
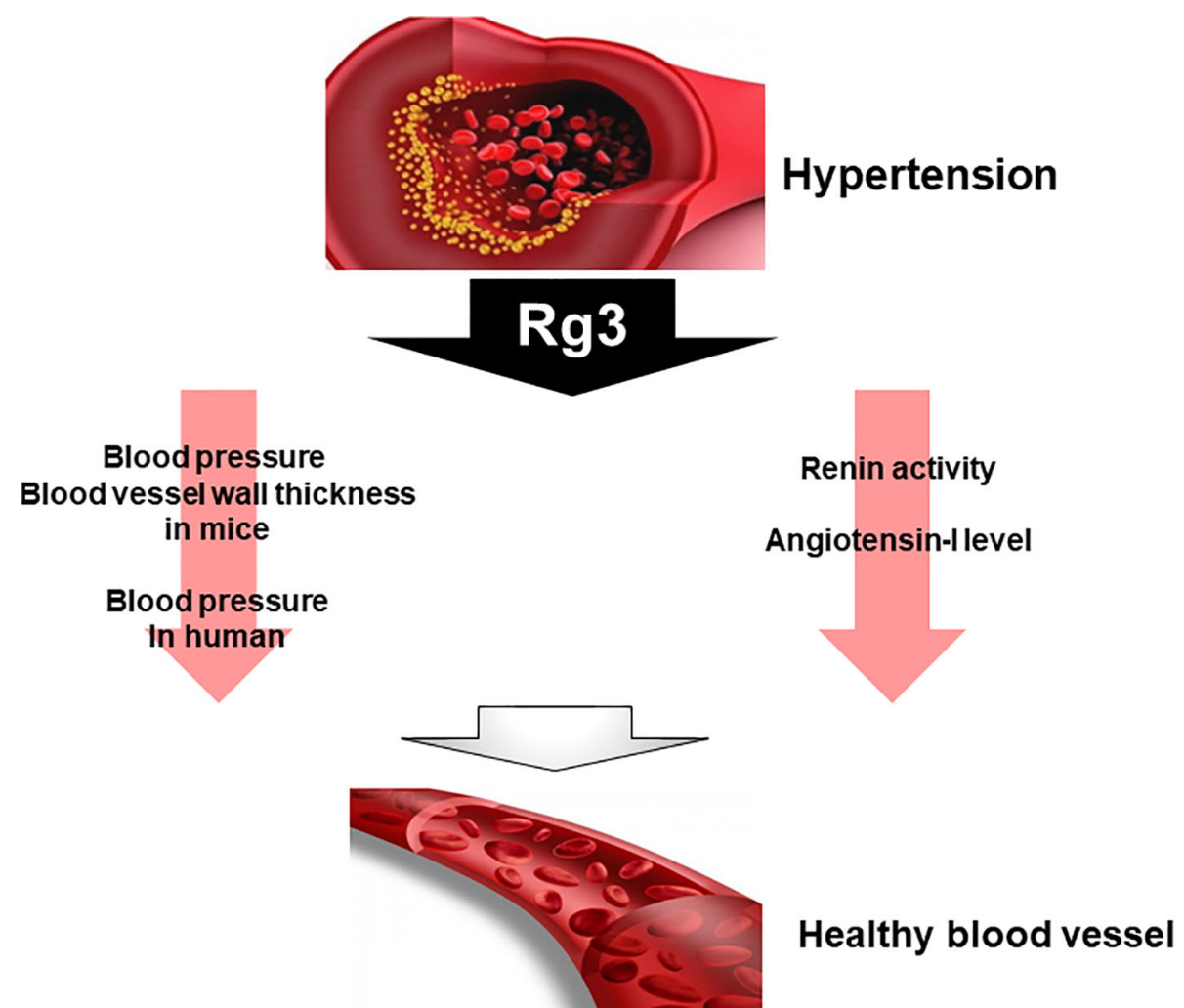

FIGURE 5 | Effect of Rg3 on hypertension. Treatment of Rg3 to hypertension mouse model decreases blood pressure and blood vessel wall thickness in mice and human. In addition, the renin activity and angiotensin-I level also decrease. 
TABLE 1 | Summary of effect of Rg3 on metabolic syndrome.

\begin{tabular}{|c|c|c|c|c|}
\hline Disease & Observation & Effect & Mechanisms of Rg3 action & Refs. \\
\hline \multirow[t]{4}{*}{ NAFLD } & $\begin{array}{l}\text { In vivo } \\
\text { (C57BL/6-HFD, db/db } \\
\text { mice) }\end{array}$ & $\begin{array}{l}\text { Reduction of bodyweight and inflammation in liver (IL-1 } \beta, \mathrm{Ph}- \\
\text { p38) }\end{array}$ & $\begin{array}{l}\text { Inhibition of pro-inflammatory cytokine } \\
\text { secretion }\end{array}$ & (Kim et al., 2019) \\
\hline & $\begin{array}{l}\text { In vivo } \\
\text { (C57BL/6-HFD) } \\
\text { In vitro } \\
\text { (3T3L1 cells) }\end{array}$ & $\begin{array}{l}\text { Reduction of TG level in WAT and liver Decrease hepatic } \\
\text { steatosis } \\
\text { Reduction of lipid accumulation and total TGs }\end{array}$ & $\begin{array}{l}\text { Inhibition of PPAR } \gamma \text { expression via } \\
\text { STAT5 phosphorylation suppress }\end{array}$ & (Lee et al., 2017) \\
\hline & $\begin{array}{l}\text { In vivo } \\
\text { (C57BL/6-HFD) }\end{array}$ & $\begin{array}{l}\text { Decrease of serum TC, LDL Decline of TC, TGs, LDL, AST, } \\
\text { AST level in liver Increase of serum leptin }\end{array}$ & Not investigated & (Nan et al., 2018) \\
\hline & $\begin{array}{l}\text { In vivo } \\
\text { (Otsuka Long-Evans } \\
\text { Tokushima Fatty rats) }\end{array}$ & $\begin{array}{l}\text { Increase of PPAR } \gamma \text { protein level and AMPK phosphorylation } \\
\text { level in liver }\end{array}$ & $\begin{array}{l}\text { Increase of PPAR } \gamma \text { protein expression } \\
\text { by promoting AMPK phosphorylation }\end{array}$ & $\begin{array}{l}\text { (Ginsberg and } \\
\text { Maccallum, 2009a) }\end{array}$ \\
\hline \multirow[t]{7}{*}{ Obesity } & $\begin{array}{l}\text { In vivo } \\
\text { (ICR mice) }\end{array}$ & Reduce of plasma glucose level & Not investigated & (Kang et al., 2008) \\
\hline & $\begin{array}{l}\text { In vitro } \\
\text { (HIT-15 cells, C2C12 } \\
\text { cells) }\end{array}$ & Increase of insulin secretion and AMPK phosphorylation & & \\
\hline & $\begin{array}{l}\text { In vitro } \\
\text { (3T3L1 cells) }\end{array}$ & $\begin{array}{l}\text { Increase GULT4 expression level and IRS-1 level } \\
\text { Increase glucose uptake }\end{array}$ & $\begin{array}{l}\text { Promotes glucose uptake via PI3K- } \\
\text { dependent pathway involving IRS-1 }\end{array}$ & (Lee et al., 2011) \\
\hline & $\begin{array}{l}\text { In vivo } \\
\text { (Otsuka Long-Evans } \\
\text { Tokushima Fatty rats) }\end{array}$ & $\begin{array}{l}\text { Decrease of body weight, fasting glucose level and } \\
\text { postprandial glucose level Increase of GLUT4 protein level, } \\
\text { PPAR } \gamma \text { protein level and AMPK phosphorylation level in } \\
\text { skeletal muscle }\end{array}$ & $\begin{array}{l}\text { Increase of PPAR } \gamma \text { protein expression } \\
\text { by promoting AMPK phosphorylation }\end{array}$ & $\begin{array}{l}\text { (Ginsberg and } \\
\text { Maccallum, 2009a) }\end{array}$ \\
\hline & $\begin{array}{l}\text { In vivo } \\
\text { (C57BL/6-HFD) }\end{array}$ & $\begin{array}{l}\text { Decrease of fat mass and plasma TC, TG level Inhibition of } \\
\text { expression lipid synthesis genes Increase of GCK and PGC1- } \\
\alpha \text { expression level }\end{array}$ & $\begin{array}{l}\text { Influencing SIRT1 signaling and } \\
\text { inhibition of its downstream genes } \\
\text { SREBP1c, FAS etc. } \\
\text { Accelerate fatty acid } \beta \text {-oxidation and } \\
\text { glycolysis pathway }\end{array}$ & (Meng et al., 2018) \\
\hline & $\begin{array}{l}\text { In vitro } \\
\text { (3T3L1 cells) }\end{array}$ & $\begin{array}{l}\text { Decrease of PPAR } \gamma \text { mRNA level } \\
\text { Increase of AMPK phosphorylation level }\end{array}$ & Not investigated & $\begin{array}{l}\text { (Hwang et al., } \\
\text { 2009) }\end{array}$ \\
\hline & $\begin{array}{l}\text { In vitro } \\
\text { (3T3L1 cells) }\end{array}$ & $\begin{array}{l}\text { Reduction of lipid accumulation } \\
\text { Increase of Glycerol secretion } \\
\text { Suppress the protein expression of PPAR } \gamma, \text { SREBP1c, C/ } \\
\text { EBP } \alpha \text { and perilipin }\end{array}$ & Not investigated & (Kong et al., 2009) \\
\hline \multirow[t]{5}{*}{ Diabetes } & $\begin{array}{l}\text { In vivo } \\
\text { (streptozotocin- } \\
\text { induced diabetic renal } \\
\text { damage model type } 1 \\
\text { diabetes) }\end{array}$ & $\begin{array}{l}\text { Inhibition of oxidative stress and AGE formation } \\
\text { Decrease the NF-KB p65, COX-2, iNOS protein levels in renal } \\
\text { cortex } \\
\text { Reduction of receptors for advanced glycation end product } \\
\text { protein levels in renal cortex }\end{array}$ & $\begin{array}{l}\text { Inhibition of NMDA receptor-mediated } \\
\text { nitrosative stress }\end{array}$ & (Kang et al., 2008) \\
\hline & $\begin{array}{l}\text { In vivo } \\
\text { (streptozotocin- } \\
\text { induced diabetic model } \\
\text { type } 1 \text { diabetes) }\end{array}$ & $\begin{array}{l}\text { Decrease the thiobarbituric acid reactive substance and NF- } \\
\text { кB p65, iNOS level in liver } \\
\text { Increase of HO-1 protein level in liver } \\
\text { Decrease the NF-кB p65, COX-2, iNOS protein levels in renal } \\
\text { cortex } \\
\text { Decrease the thiobarbituric acid reactive substance and AGE } \\
\text { formation }\end{array}$ & Not investigated & $\begin{array}{l}\text { (Yokozawa et al., } \\
\text { 2007) }\end{array}$ \\
\hline & $\begin{array}{l}\text { In vivo } \\
\text { (Otsuka Long-Evans } \\
\text { Tokushima fatty rats) }\end{array}$ & $\begin{array}{l}\text { Decrease of body weight, fasting glucose level and } \\
\text { postprandial glucose level }\end{array}$ & $\begin{array}{l}\text { Increase of PPAR } \gamma \text { protein expression } \\
\text { by promoting AMPK phosphorylation }\end{array}$ & $\begin{array}{l}\text { (Ginsberg and } \\
\text { Maccallum, 2009b) }\end{array}$ \\
\hline & $\begin{array}{l}\text { In vivo } \\
\text { (streptozotocin- } \\
\text { induced diabetic model } \\
\text { type } 1 \text { diabetes) }\end{array}$ & $\begin{array}{l}\text { Decrease the blood glucose } \\
\text { Reduction the hepatic glycogen and cholesterol level }\end{array}$ & Not investigated & (Liu et al., 2009) \\
\hline & $\begin{array}{l}\text { In vivo } \\
(\mathrm{db} / \mathrm{db} \text { mice })\end{array}$ & Increase the GLP1 secretion & $\begin{array}{l}\text { Stimulation GLP-1 secretion by } \\
\text { activating sweet taste receptor signal }\end{array}$ & (Kim et al., 2015) \\
\hline \multirow[t]{2}{*}{ Hypertension } & $\begin{array}{l}\text { In vivo } \\
\text { (spontaneously } \\
\text { hypertensive rats) }\end{array}$ & Reduction of blood pressure and blood vessel wall thickness & Not investigated & (Lee et al., 2016) \\
\hline & $\begin{array}{l}\text { In vivo } \\
\text { (C57BL/6) }\end{array}$ & Decrease the renin activity and angiotensin-I level & Not investigated & (Nagar et al., 2016) \\
\hline
\end{tabular}




\section{CONCLUSION}

Many studies on the association between ginseng and metabolic syndrome have been reported (Table 1). However, the relationship between metabolic syndrome and $\operatorname{Rg} 3$ requires further study. Interestingly, Rg3 efficacy is subdivided by its molecular forms (S form and R form). But these studies also mainly focus on the pathway of Rg3 action. In addition, in obesity and diabetic animal models, only the effects of RG3 on phenotype are reported. Metabolic syndrome has complex risk factors, but better understanding of Rg3 could lead to a cure. And, based on these studies, no actual clinical treatment is underway. It is urgently necessary to study detailed and logical molecular mechanisms by $\mathrm{Rg} 3 . \mathrm{Rg} 3$ studies on islets most closely associated with diabetes and insulin resistance are quite lacing. If research on the effects of Rg3 on islet function and molecular pathway, therapies for type 1 and type 2 diabetes may be proposed. Rg3 may also be incorporated into myotropia caused by diabetes and obesity. If study on satellite cell, not just myoblast and myocyte, is carried out, a prophylactic effect can be expected. For use of Rg3 as a therapeutic agent for obesity and diabetes, the pathways and genes affected by this compound require thorough investigation.

\section{REFERENCES}

Alba, L. M., and Lindor, K. (2003). Review article: Non-alcoholic fatty liver disease. Aliment. Pharmacol. Ther. 17 (8), 977-986. doi: 10.1046/j.1365-2036.2003. 01493.x

American Diabetes, A (2014). Standards of medical care in diabetes-2014. Diabetes Care 37 (Suppl 1), S14-S80. doi: 10.2337/dc14-S014

Angulo, P. (2003). Current best treatment for non-alcoholic fatty liver disease. Expert Opin. Pharmacother. 4 (5), 611-623. doi: 10.1517/14656566.4.5.611

Azzout-Marniche, D., Becard, D., Guichard, C., Foretz, M., Ferre, P., and Foufelle, F. (2000). Insulin effects on sterol regulatory-element-binding protein-1c (SREBP1c) transcriptional activity in rat hepatocytes. Biochem. J. $350 \mathrm{Pt} 2,389-393$. doi: 10.1042/bj3500389

Balcazar-Munoz, B. R., Martinez-Abundis, E., and Gonzalez-Ortiz, M. (2003). [Effect of oral inulin administration on lipid profile and insulin sensitivity in subjects with obesity and dyslipidemia]. Rev. Med. Chil. 131 (6), 597-604. doi: 10.4067/S0034-98872003000600002

Basen-Engquist, K., and Chang, M. (2011). Obesity and cancer risk: recent review and evidence. Curr. Oncol. Rep. 13 (1), 71-76. doi: 10.1007/s11912-010-0139-7

Bjorntorp, P. (1991). Metabolic implications of body fat distribution. Diabetes Care 14 (12), 1132-1143. doi: 10.2337/diacare.14.12.1132

Browning, J. D., and Horton, J. D. (2004). Molecular mediators of hepatic steatosis and liver injury. J. Clin. Invest. 114 (2), 147-152. doi: 10.1172/JCI200422422

Campaigne, B. N. (1990). Body fat distribution in females: metabolic consequences and implications for weight loss. Med. Sci. Sports Exerc. 22 (3), 291-297. doi: 10.1249/00005768-199006000-00004

Charlton, M., Sreekumar, R., Rasmussen, D., Lindor, K., and Nair, K. S. (2002). Apolipoprotein synthesis in nonalcoholic steatohepatitis. Hepatology 35 (4), 898-904. doi: 10.1053/jhep.2002.32527

Chen, J., and Huang, X. F. (2009). Adiponectin in obesity-associated colon cancer and its preventive implications: comment on Association of visceral fat accumulation and adiponectin levels with colorectal neoplasia. Dig Dis. Sci. 54 (8), 1810-1811. doi: 10.1007/s10620-009-0857-6

Cho, E., Manson, J. E., Stampfer, M. J., Solomon, C. G., Colditz, G. A., Speizer, F. E., et al. (2002). A prospective study of obesity and risk of coronary heart disease among diabetic women. Diabetes Care 25 (7), 1142-1148. doi: 10.2337/ diacare.25.7.1142

Colica, C., and Abenavoli, L. (2018). Resistin Levels in Non-alcoholic Fatty Liver Disease Pathogenesis. J. Transl. Int. Med. 6 (1), 52-53. doi: 10.2478/jtim-2018-0011

\section{AUTHOR CONTRIBUTIONS}

HL, GK, JiP, QT, and JoP contributed conception and design of the study. HL, JiP, and CK organized the database. HL wrote the first draft of the manuscript. HL, GK, QT, JiP, CK, and JoP wrote sections of the manuscript. All authors contributed to manuscript revision, read and approved the submitted version.

\section{FUNDING}

This work was financially supported by a research fund from Chungnam National University (grant to JoP) and by the Brain Korea 21 PLUS Project for Medical Science, Chungnam National University School of Medicine.

\section{ACKNOWLEDGMENTS}

Dr. S.J. Lee (Sookmyung Women's University, Korea) is acknowledged for the critical discussion of the manuscript.

Das, S. K., and Balakrishnan, V. (2011). Role of cytokines in the pathogenesis of non-alcoholic Fatty liver disease. Indian J. Clin. Biochem. 26 (2), 202-209. doi: 10.1007/s12291-011-0121-7

DeFronzo, R. A., Ferrannini, E., Groop, L., Henry, R. R., Herman, W. H., Holst, J. J., et al. (2015). Type 2 diabetes mellitus. Nat. Rev. Dis. Primers 1, 15019. doi: $10.1038 /$ nrdp. 2015.19

Defronzo, R. A. (2006). Is insulin resistance atherogenic? Possible mechanisms. Atheroscler. Suppl. 7 (4), 11-15. doi: 10.1016/j.atherosclerosissup.2006.05.002

Defronzo, R. A. (2009). Banting Lecture. From the triumvirate to the ominous octet: a new paradigm for the treatment of type 2 diabetes mellitus. Diabetes 58 (4), 773-795. doi: 10.2337/db09-9028

Despres, J. P., Moorjani, S., Lupien, P. J., Tremblay, A., Nadeau, A., and Bouchard, C. (1990). Regional distribution of body fat, plasma lipoproteins, and cardiovascular disease. Arteriosclerosis 10 (4), 497-511. doi: 10.1161/01.ATV.10.4.497

Dowman, J. K., Tomlinson, J. W., and Newsome, P. N. (2010). Pathogenesis of nonalcoholic fatty liver disease. QJM 103 (2), 71-83. doi: 10.1093/qjmed/hcp158

Duvnjak, M., Lerotic, I., Barsic, N., Tomasic, V., Virovic Jukic, L., and Velagic, V. (2007). Pathogenesis and management issues for non-alcoholic fatty liver disease. World J. Gastroenterol. 13 (34), 4539-4550. doi: 10.3748/wjg.v13.i34.4539

Eckel, R. H., Kahn, R., Robertson, R. M., and Rizza, R. A. (2006). Preventing cardiovascular disease and diabetes: a call to action from the American Diabetes Association and the American Heart Association. Circulation 113 (25), 2943-2946. doi: 10.1161/CIRCULATIONAHA.106.176583

Fan, X., Xu, Y., Zhu, D., and Ji, Y. (2017). Pharmacokinetic Comparison of 20(R)- and 20(S)-Ginsenoside Rh1 and 20(R)- and 20(S)-Ginsenoside Rg3 in rat plasma following oral administration of radix ginseng rubra and sheng-mai-san extracts. Evid. Based Complement. Alternat. Med. 2017, 6451963. doi: 10.1155/2017/6451963

Feldstein, A. E., Canbay, A., Angulo, P., Taniai, M., Burgart, L. J., Lindor, K. D., et al. (2003). Hepatocyte apoptosis and fas expression are prominent features of human nonalcoholic steatohepatitis. Gastroenterology 125 (2), 437-443. doi: 10.1016/S0016-5085(03)00907-7

Ferrannini, E., and Iozzo, P. (2006). Is insulin resistance atherogenic? A review of the evidence. Atheroscler. Suppl. 7 (4), 5-10. doi: 10.1016/j.atherosclerosissup.2006.05.006

Finkelstein, E. A., Khavjou, O. A., Thompson, H., Trogdon, J. G., Pan, L., Sherry, B., et al. (2012). Obesity and severe obesity forecasts through 2030. Am. J. Prev. Med. 42 (6), 563-570. doi: 10.1016/j.amepre.2011.10.026

Gaemers, I. C., and Groen, A. K. (2006). New insights in the pathogenesis of nonalcoholic fatty liver disease. Curr. Opin. Lipidol. 17 (3), 268-273. doi: 10.1097/ 01.mol.0000226118.43178.98 
Gao, Y., Chu, S., Zhang, Z., and Chen, N. (2017). Hepataprotective effects of ginsenoside Rg1 - A review. J. Ethnopharmacol. 206, 178-183. doi: 10.1016/ j.jep.2017.04.012

Ginsberg, H. N., and Maccallum, P. R. (2009a). The obesity, metabolic syndrome, and type 2 diabetes mellitus pandemic: II. Therapeutic management of atherogenic dyslipidemia. J. Clin. Hypertens. (Greenwich) 11 (9), 520-527. doi: $10.1111 /$ j.1559-4572.2009.00060.x

Ginsberg, H. N., and MacCallum, P. R. (2009b). The obesity, metabolic syndrome, and type 2 diabetes mellitus pandemic: Part I. Increased cardiovascular disease risk and the importance of atherogenic dyslipidemia in persons with the metabolic syndrome and type 2 diabetes mellitus. J. Cardiometab. Syndr. 4 (2), 113-119. doi: 10.1111/j.1559-4572.2008.00044.x

Grundy, S. M. (2008). Metabolic syndrome pandemic. Arterioscler. Thromb. Vasc. Biol. 28 (4), 629-636. doi: 10.1161/ATVBAHA.107.151092

Grundy, S. M. (2016). Metabolic syndrome update. Trends Cardiovasc. Med. 26 (4), 364-373. doi: 10.1016/j.tcm.2015.10.004

Guillet-Deniau, I., Mieulet, V., Le Lay, S., Achouri, Y., Carre, D., Girard, J., et al. (2002). Sterol regulatory element binding protein-1c expression and action in rat muscles: insulin-like effects on the control of glycolytic and lipogenic enzymes and UCP3 gene expression. Diabetes 51 (6), 1722-1728. doi: 10.2337/ diabetes.51.6.1722

Helms, S. (2004). Cancer prevention and therapeutics: Panax ginseng. Altern. Med. Rev. 9 (3), 259-274.

Hotamisligil, G. S., Shargill, N. S., and Spiegelman, B. M. (1993). Adipose expression of tumor necrosis factor-alpha: direct role in obesity-linked insulin resistance. Science 259 (5091), 87-91. doi: 10.1126/science.7678183

Howard, B. V., Ruotolo, G., and Robbins, D. C. (2003). Obesity and dyslipidemia. Endocrinol. Metab. Clin. North Am. 32 (4), 855-867. doi: 10.1016/S0889-8529 (03)00073-2

Hwang, J. T., Lee, M. S., Kim, H. J., Sung, M. J., Kim, H. Y., Kim, M. S., et al. (2009). Antiobesity effect of ginsenoside Rg3 involves the AMPK and PPAR-gamma signal pathways. Phytother. Res. 23 (2), 262-266. doi: 10.1002/ptr.2606

Jovanovski, E., Bateman, E. A., Bhardwaj, J., Fairgrieve, C., Mucalo, I., Jenkins, A. L., et al. (2014). Effect of Rg3-enriched Korean red ginseng (Panax ginseng) on arterial stiffness and blood pressure in healthy individuals: a randomized controlled trial. $J$. Am. Soc. Hypertens. 8 (8), 537-541. doi: 10.1016/j.jash.2014.04.004

Junmin, S., Hongxiang, L., Zhen, L., Chao, Y., and Chaojie, W. (2015). Ginsenoside Rg3 inhibits colon cancer cell migration by suppressing nuclear factor kappa B activity. J. Tradit. Chin. Med. 35 (4), 440-444. doi: 10.1016/S0254-6272(15) 30122-9

Kang, K. S., Yamabe, N., Kim, H. Y., Park, J. H., and Yokozawa, T. (2008). Therapeutic potential of $20(\mathrm{~S})$-ginsenoside $\operatorname{Rg}(3)$ against streptozotocininduced diabetic renal damage in rats. Eur. J. Pharmacol. 591 (1-3), 266272. doi: 10.1016/j.ejphar.2008.06.077

Karikura, M., Miyase, T., Tanizawa, H., Takino, Y., Taniyama, T., and Hayashi, T. (1990). Studies on absorption, distribution, excretion and metabolism of ginseng saponins. V. The decomposition products of ginsenoside $\mathrm{Rb} 2$ in the large intestine of rats. Chem. Pharm. Bull. (Tokyo) 38 (10), 2859-2861. doi: 10.1248/cpb.38.2859

Karikura, M., Miyase, T., Tanizawa, H., Taniyama, T., and Takino, Y. (1991a). Studies on absorption, distribution, excretion and metabolism of ginseng saponins. VI. The decomposition products of ginsenoside Rb2 in the stomach of rats. Chem. Pharm. Bull. (Tokyo) 39 (2), 400-404. doi: 10.1248/ cpb.39.400

Karikura, M., Miyase, T., Tanizawa, H., Taniyama, T., and Takino, Y. (1991b). Studies on absorption, distribution, excretion and metabolism of ginseng saponins. VII. Comparison of the decomposition modes of ginsenoside-Rb1 and $-\mathrm{Rb} 2$ in the digestive tract of rats. Chem. Pharm. Bull. (Tokyo) 39 (9), 2357-2361. doi: 10.1248/cpb.39.2357

Kim, I. W., Sun, W. S., Yun, B. S., Kim, N. R., Min, D., and Kim, S. K. (2013). Characterizing a full spectrum of physico-chemical properties of (20S)- and (20R)-ginsenoside $\mathrm{Rg} 3$ to be proposed as standard reference materials. J. Ginseng Res. 37 (1), 124-134. doi: 10.5142/jgr.2013.37.124

Kim, D. G., Jung, K. H., Lee, D. G., Yoon, J. H., Choi, K. S., Kwon, S. W., et al. (2014). 20(S)-Ginsenoside Rg3 is a novel inhibitor of autophagy and sensitizes hepatocellular carcinoma to doxorubicin. Oncotarget 5 (12), 4438-4451. doi: 10.18632/oncotarget.2034
Kim, Y. J., Zhang, D., and Yang, D. C. (2015). Biosynthesis and biotechnological production of ginsenosides. Biotechnol. Adv. 33 (6 Pt 1), 717-735. doi: 10.1016/ j.biotechadv.2015.03.001

Kim, D. S., Kim, B. C., Daily, J. W., and Park, S. (2018). High genetic risk scores for impaired insulin secretory capacity doubles the risk for type 2 diabetes in Asians and is exacerbated by Western-type diets. Diabetes Metab. Res. Rev. 34 (1), 1-9 doi: 10.1002/dmrr.2944

Kim, J. C., Jeon, J. Y., Yang, W. S., Kim, C. H., and Eom, D. W. (2019). Combined amelioration of ginsenoside ( $\mathrm{Rg} 1, \mathrm{Rb} 1$, and $\mathrm{Rg} 3$ )-enriched korean red ginseng and probiotic lactobacillus on non-alcoholic fatty liver disease. Curr. Pharm. Biotechnol. 20 (3), 222-231. doi: 10.2174/1389201020666190311143554

Kissebah, A. H., and Krakower, G. R. (1994). Regional adiposity and morbidity. Physiol. Rev. 74 (4), 761-811. doi: 10.1152/physrev.1994.74.4.761

Klein, S., Mittendorfer, B., Eagon, J. C., Patterson, B., Grant, L., Feirt, N., et al. (2006). Gastric bypass surgery improves metabolic and hepatic abnormalities associated with nonalcoholic fatty liver disease. Gastroenterology 130 (6), 1564-1572. doi: 10.1053/j.gastro.2006.01.042

Kong, C. S., Kim, J. A., and Kim, S. K. (2009). Anti-obesity effect of sulfated glucosamine by AMPK signal pathway in 3T3-L1 adipocytes. Food Chem. Toxicol. 47 (10), 2401-2406. doi: 10.1016/j.fct.2009.06.010

Konishi, M., Sugiyama, S., Sugamura, K., Nozaki, T., Ohba, K., Matsubara, J., et al. (2010). Association of pericardial fat accumulation rather than abdominal obesity with coronary atherosclerotic plaque formation in patients with suspected coronary artery disease. Atherosclerosis 209 (2), 573-578. doi: 10.1016/j.atherosclerosis.2009.10.008

Kwok, H. H., Guo, G. L., Lau, J. K., Cheng, Y. K., Wang, J. R., Jiang, Z. H., et al. (2012). Stereoisomers ginsenosides-20(S)- $\operatorname{Rg}(3)$ and $-20(\mathrm{R})-\mathrm{Rg}(3)$ differentially induce angiogenesis through peroxisome proliferator-activated receptorgamma. Biochem. Pharmacol. 83 (7), 893-902. doi: 10.1016/j.bcp.2011.12.039

Lee, J., Lee, E., Kim, D., Lee, J., Yoo, J., and Koh, B. (2009). Studies on absorption, distribution and metabolism of ginseng in humans after oral administration. J. Ethnopharmacol. 122 (1), 143-148. doi: 10.1016/j.jep.2008.12.012

Lee, O. H., Lee, H. H., Kim, J. H., and Lee, B. Y. (2011). Effect of ginsenosides Rg3 and Re on glucose transport in mature 3T3-L1 adipocytes. Phytother. Res. 25 (5), 768-773. doi: 10.1002/ptr.3322

Lee, H., Park, D., and Yoon, M. (2013). Korean red ginseng (Panax ginseng) prevents obesity by inhibiting angiogenesis in high fat diet-induced obese C57BL/6J mice. Food Chem. Toxicol. 53, 402-408. doi: 10.1016/ j.fct.2012.11.052

Lee, K. H., Bae, I. Y., Park, S. I., Park, J. D., and Lee, H. G. (2016). Antihypertensive effect of Korean Red Ginseng by enrichment of ginsenoside $\mathrm{Rg} 3$ and argininefructose. J. Ginseng Res. 40 (3), 237-244. doi: 10.1016/j.jgr.2015.08.002

Lee, J. B., Yoon, S. J., Lee, S. H., Lee, M. S., Jung, H., Kim, T. D., et al. (2017). Ginsenoside Rg3 ameliorated HFD-induced hepatic steatosis through downregulation of STAT5-PPARgamma. J. Endocrinol. 235 (3), 223-235. doi: 10.1530/JOE-17-0233

Lee, H., Hong, Y., Tran, Q., Cho, H., Kim, M., Kim, C., et al. (2019). A new role for the ginsenoside RG3 in antiaging via mitochondria function in ultraviolet-irradiated human dermal fibroblasts. J. Ginseng Res. 43 (3), 431441. doi: $10.1016 /$ j.jgr.2018.07.003

Leong, K. S., and Wilding, J. P. (1999). Obesity and diabetes. Baillieres Best Pract. Res. Clin. Endocrinol. Metab. 13 (2), 221-237. doi: 10.1053/beem.1999.0017

Li, G., Zhang, N., Geng, F., Liu, G., Liu, B., Lei, X., et al. (2019). High-throughput metabolomics and ingenuity pathway approach reveals the pharmacological effect and targets of Ginsenoside Rg1 in Alzheimer's disease mice. Sci. Rep. 9 (1), 7040. doi: 10.1038/s41598-019-43537-4

Li, W., Jiang, Y., Liu, Y., Li, C., and Fan, D. (2019). [Biocatalytic strategies in producing ginsenoside by glycosidase-a review]. Sheng Wu Gong Cheng Xue Bao 35 (9), 1590-1606. doi: 10.13345/j.cjb.190054

Liu, Z., Wang, L. J., Li, X., Hu, J. N., Chen, Y., Ruan, C. C., et al. (2009). Hypoglycemic effects of malonyl-ginsenosides extracted from roots of Panax ginseng on streptozotocin-induced diabetic mice. Phytother. Res. 23 (10), 1426-1430. doi: 10.1002/ptr.2796

Lonardo, A., Sookoian, S., Chonchol, M., Loria, P., and Targher, G. (2013). Cardiovascular and systemic risk in nonalcoholic fatty liver disease atherosclerosis as a major player in the natural course of NAFLD. Curr Pharm. Des. 19 (29), 5177-5192. doi: 10.2174/1381612811319290003 
Lovejoy, J. C., de la Bretonne, J. A., Klemperer, M., and Tulley, R. (1996). Abdominal fat distribution and metabolic risk factors: effects of race. Metabolism 45 (9), 1119-1124. doi: 10.1016/S0026-0495(96)90011-6

Ludwig, J., Viggiano, T. R., McGill, D. B., and Oh, B. J. (1980). Nonalcoholic steatohepatitis: Mayo Clinic experiences with a hitherto unnamed disease. Mayo Clin. Proc. 55 (7), 434-438.

Matsuda, H., Namba, K., Fukuda, S., Tani, T., and Kubo, M. (1986). Pharmacological study on Panax ginseng C. A. Meyer. IV. Effects of red ginseng on experimental disseminated intravascular coagulation. (3). Effect of ginsenoside-Ro on the blood coagulative and fibrinolytic system. Chem. Pharm. Bull. (Tokyo) 34 (5), 2100-2104. doi: 10.1248/cpb.34.2100

Maury, E., and Brichard, S. M. (2010). Adipokine dysregulation, adipose tissue inflammation and metabolic syndrome. Mol. Cell Endocrinol. 314 (1), 1-16. doi: 10.1016/j.mce.2009.07.031

Meng, J., Hu, X., Zhang, T., Dong, P., Li, Z., Xue, C., et al. (2018). Saponin from sea cucumber exhibited more significant effects than ginsenoside on ameliorating high fat diet-induced obesity in C57BL/6 mice. Medchemcomm 9 (4), 725-734. doi: 10.1039/C7MD00653E

Nagar, H., Choi, S., Jung, S. B., Jeon, B. H., and Kim, C. S. (2016). Rg3-enriched Korean Red Ginseng enhances blood pressure stability in spontaneously hypertensive rats. Integr. Med. Res. 5 (3), 223-229. doi: 10.1016/ j.imr.2016.05.006

Nakhjavani, M., Hardingham, J. E., Palethorpe, H. M., Tomita, Y., Smith, E., Price, T. J., et al. (2019). Ginsenoside Rg3: potential molecular targets and therapeutic indication in metastatic breast cancer. Medicines (Basel) 6 (1), 1-20. doi: 10.3390/medicines6010017

Nakhjavani, M., Palethorpe, H. M., Tomita, Y., Smith, E., Price, T. J., Yool, A. J., et al. (2019). Stereoselective anti-cancer activities of ginsenoside Rg3 on triple negative breast cancer cell models. Pharmaceuticals (Basel) 12 (3), 1-14. doi: 10.3390/ph12030117

Nan, B., Liu, Y. L., You, Y., Li, W. C., Fan, J. J., Wang, Y. S., et al. (2018). Protective effects of enhanced minor ginsenosides in Lactobacillus fermentum KP-3fermented ginseng in mice fed a high fat diet. Food Funct. 9 (11), 6020-6028. doi: $10.1039 / \mathrm{C} 8 \mathrm{FO} 01056 \mathrm{~K}$

Nolan, P. B., Carrick-Ranson, G., Stinear, J. W., Reading, S. A., and Dalleck, L. C. (2017). Prevalence of metabolic syndrome and metabolic syndrome components in young adults: a pooled analysis. Prev. Med. Rep. 7, 211-215. doi: 10.1016/j.pmedr.2017.07.004

Odani, T., Tanizawa, H., and Takino, Y. (1983). Studies on the absorption, distribution, excretion and metabolism of ginseng saponins. II. The absorption, distribution and excretion of ginsenoside Rg1 in the rat. Chem. Pharm. Bull. (Tokyo) 31 (1), 292-298. doi: 10.1248/cpb.31.292

Ogden, C. L., Carroll, M. D., Kit, B. K., and Flegal, K. M. (2014). Prevalence of childhood and adult obesity in the United States 2011-2012. JAMA 311 (8), 806-814. doi: 10.1001/jama.2014.732

Oladejo, A. O. (2011). Overview of the metabolic syndrome; an emerging pandemic of public health significance. Ann. Ib Postgrad. Med. 9 (2), 78-82.

Park, Y. H., Kim, Y. C., Park, S. U., Lim, H. S., Kim, J. B., Cho, B. K., et al. (2012). Age-dependent Distribution of Fungal Endophytes in Panax ginseng Roots Cultivated in Korea. J. Ginseng Res. 36 (3), 327-333. doi: 10.5142/ jgr.2012.36.3.327

Patel, V., Sanyal, A. J., and Sterling, R. (2016). Clinical presentation and patient evaluation in nonalcoholic fatty liver disease. Clin. Liver Dis. 20 (2), 277-292. doi: 10.1016/ j.cld.2015.10.006

Peng, L., Sun, S., Xie, L. H., Wicks, S. M., and Xie, J. T. (2012). Ginsenoside Re: pharmacological effects on cardiovascular system. Cardiovasc. Ther. 30 (4), e183-e188. doi: 10.1007/978-1-61779-523-7

Petta, S., Muratore, C., and Craxi, A. (2009). Non-alcoholic fatty liver disease pathogenesis: the present and the future. Dig Liver Dis. 41 (9), 615-625. doi: 10.1016/j.dld.2009.01.004

Ramanjaneya, M., Chen, J., Brown, J. E., Tripathi, G., Hallschmid, M., Patel, S., et al. (2010). Identification of nesfatin-1 in human and murine adipose tissue: a novel depot-specific adipokine with increased levels in obesity. Endocrinology 151 (7), 3169-3180. doi: 10.1210/en.2009-1358

Ramsay, T. G., and Caperna, T. J. (2009). Ontogeny of adipokine expression in neonatal pig adipose tissue. Comp. Biochem. Physiol. B Biochem. Mol. Biol. 152 (1), 72-78. doi: 10.1016/j.cbpb.2008.09.088
Ryo, M., Funahashi, T., Nakamura, T., Kihara, S., Kotani, K., Tokunaga, K., et al. (2014). Fat accumulation and obesity-related cardiovascular risk factors in middle-aged Japanese men and women. Intern Med. 53 (4), 299-305. doi: 10.2169/ internalmedicine.53.9476

Saklayen, M. G. (2018). The Global Epidemic of the Metabolic Syndrome. Curr. Hypertens. Rep. 20 (2), 12. doi: 10.1007/s11906-018-0812-z

Shin, Y. M., Jung, H. J., Choi, W. Y., and Lim, C. J. (2013). Antioxidative, antiinflammatory, and matrix metalloproteinase inhibitory activities of 20(S)ginsenoside Rg3 in cultured mammalian cell lines. Mol. Biol. Rep. 40 (1), 269-279. doi: 10.1007/s11033-012-2058-1

Siddiqi, M. H., Siddiqi, M. Z., Kang, S., Noh, H. Y., Ahn, S., Simu, S. Y., et al. (2015). Inhibition of osteoclast differentiation by ginsenoside Rg3 in RAW264.7 cells via RANKL, JNK and p38 MAPK pathways through a modulation of cathepsin K: an in silico and in vitro study. Phytother. Res. 29 (9), 1286-1294. doi: 10.1002/ptr.5374

Smith, U. (2015). Abdominal obesity: a marker of ectopic fat accumulation. J. Clin. Invest. 125 (5), 1790-1792. doi: 10.1172/JCI81507

Sun, M., Ye, Y., Xiao, L., Duan, X., Zhang, Y., and Zhang, H. (2017). Anticancer effects of ginsenoside Rg3 (review). Int. J. Mol. Med. 39 (3), 507-518. doi: 10.3892/ijmm.2017.2857

Takino, Y., Odani, T., Tanizawa, H., and Hayashi, T. (1982). Studies on the absorption, distribution, excretion and metabolism of ginseng saponins. I. Quantitative analysis of ginsenoside Rg1 in rats. Chem. Pharm. Bull. (Tokyo) 30 (6), 2196-2201. doi: 10.1248/cpb.30.2196

Tam, D. N. H., Truong, D. H., Nguyen, T. T. H., Quynh, L. N., Tran, L., Nguyen, H. D., et al. (2018). Ginsenoside Rh1: a systematic review of its pharmacological properties. Planta Med. 84 (3), 139-152. doi: 10.1055/s-0043-124087

Tariq, H., Nayudu, S., Akella, S., Glandt, M., and Chilimuri, S. (2016). Nonalcoholic fatty pancreatic disease: a review of literature. Gastroenterology Res. 9 (6), 87-91. doi: 10.14740/gr731w

Tian, J., Fu, F., Geng, M., Jiang, Y., Yang, J., Jiang, W., et al. (2005). Neuroprotective effect of 20 (S)-ginsenoside $\mathrm{Rg} 3$ on cerebral ischemia in rats. Neurosci. Lett. 374 (2), 92-97. doi: 10.1016/j.neulet.2004.10.030

Uysal, K. T., Wiesbrock, S. M., Marino, M. W., and Hotamisligil, G. S. (1997). Protection from obesity-induced insulin resistance in mice lacking TNF-alpha function. Nature 389 (6651), 610-614. doi: 10.1038/39335

van Namen, M., Prendergast, L., and Peiris, C. (2019). Supervised lifestyle intervention for people with metabolic syndrome improves outcomes and reduces individual risk factors of metabolic syndrome: A systematic review and meta-analysis. Metabolism 101, 153988. doi: 10.1016/j.metabol.2019.153988

Ventre, J., Doebber, T., Wu, M., MacNaul, K., Stevens, K., Pasparakis, M., et al. (1997). Targeted disruption of the tumor necrosis factor-alpha gene: metabolic consequences in obese and nonobese mice. Diabetes 46 (9), 1526-1531. doi: 10.2337/diab.46.9.1526

Wang, J. T., and Liu, Y. L. (2003). Non-alcoholic fatty liver disease: the problems we are facing. Hepatobiliary Pancreat. Dis. Int. 2 (3), 334-337.

Wei, X., Su, F., Su, X., Hu, T., and Hu, S. (2012). Stereospecific antioxidant effects of ginsenoside $\operatorname{Rg} 3$ on oxidative stress induced by cyclophosphamide in mice. Fitoterapia 83 (4), 636-642. doi: 10.1016/j.fitote.2012.01.006

Xie, C. L., Wang, W. W., Xue, X. D., Zhang, S. F., Gan, J., and Liu, Z. G. (2015). A systematic review and meta-analysis of Ginsenoside-Rg1 (G-Rg1) in experimental ischemic stroke. Sci. Rep. 5, 7790. doi: 10.1038/srep07790

Xu, T., Jin, Z., Yuan, Y., Wei, H., Xu, X., He, S., et al. (2016). Ginsenoside Rg3 serves as an adjuvant chemotherapeutic agent and VEGF inhibitor in the treatment of non-small cell lung cancer: a meta-analysis and systematic review. Evid. Based Complement. Alternat. Med. 2016, 7826753. doi: 10.1155/2016/ 7826753

Yokozawa, T., Kang, K. S., Yamabe, N., and Kim, H. Y. (2007). Therapeutic potential of heat-processed Panax ginseng with respect to oxidative tissue damage. Drug Discov. Ther. 1 (1), 30-44.

Yoon, S. J., Park, J. Y., Choi, S., Lee, J. B., Jung, H., Kim, T. D., et al. (2015). Ginsenoside Rg3 regulates S-nitrosylation of the NLRP3 inflammasome via suppression of iNOS. Biochem. Biophys. Res. Commun. 463 (4), 1184-1189. doi: 10.1016/j.bbrc.2015.06.080

Younossi, Z. M., Gramlich, T., Liu, Y. C., Matteoni, C., Petrelli, M., Goldblum, J., et al. (1998). Nonalcoholic fatty liver disease: assessment of variability in pathologic interpretations. Mod. Pathol. 11 (6), 560-565. 
Younossi, Z., Anstee, Q. M., Marietti, M., Hardy, T., Henry, L., Eslam, M., et al. (2018). Global burden of NAFLD and NASH: trends, predictions, risk factors and prevention. Nat. Rev. Gastroenterol. Hepatol. 15 (1), 11-20. doi: 10.1038/ nrgastro.2017.109

Zhao, Z. F., Wei, H. Y., Guo, Y. L., and Gu, W. (2016). [Potential distribution of Panax ginseng and its predicted responses to climate change.]. Ying Yong Sheng Tai Xue Bao 27 (11), 3607-3615. doi: 10.13287/j.1001-9332.201611.040

Zhou, Y. J., Li, Y. Y., Nie, Y. Q., Huang, C. M., and Cao, C. Y. (2012). Natural course of nonalcoholic fatty liver disease in southern China: a prospective cohort study. J. Dig Dis. 13 (3), 153-160. doi: 10.1111/j.1751-2980.2011. 00571.x

Zhou, P., Xie, W., Sun, Y., Dai, Z., Li, G., Sun, G., et al. (2019). Ginsenoside Rb1 and mitochondria: a short review of the literature. Mol. Cell Probes 43, 1-5. doi: 10.1016/j.mcp.2018.12.001
Zitkus, B. S. (2014). Update on the american diabetes association standards of medical care. Nurse Pract. 39 (8), 22-32;quiz 32-23. doi: 10.1097/ 01.NPR.0000451880.48790.50

Conflict of Interest: The authors declare that the research was conducted in the absence of any commercial or financial relationships that could be construed as a potential conflict of interest.

Copyright (c) 2020 Lee, Kong, Tran, Kim, Park and Park. This is an open-access article distributed under the terms of the Creative Commons Attribution License (CC BY). The use, distribution or reproduction in other forums is permitted, provided the original author(s) and the copyright owner(s) are credited and that the original publication in this journal is cited, in accordance with accepted academic practice. No use, distribution or reproduction is permitted which does not comply with these terms. 